\title{
ESTUDIO DE GENÉTICA DEL VIRUS DE LA HEPATITIS C EN CULTIVOS CELULARES
}

\section{GENETICS STUDY OF HEPATITIS C VIRUS IN CELL CULTURE}

\author{
Manzanares Ibáñez, Mónica
}

Facultad de Veterinaria de la Universidad Complutense de Madrid, España Correspondencia: monica.manzanares.25@gmail.com

\section{RESUMEN}

El virus de la hepatitis C infecta a unos 170 millones de personas en todo el mundo, dando lugar en muchos de los pacientes afectados a cirrosis y carcinoma hepatocelular. Aunque en los últimos años se ha avanzado mucho en su conocimiento gracias a que se consiguió el desarrollo y la optimización de un sistema de cultivo celular, aún hay etapas de su ciclo de replicación que no se comprenden totalmente, y muchas de las funciones de las proteínas virales aún no están claras. Con el fin de dilucidar el papel que juegan dos de estas proteínas en el desarrollo de carcinoma hepatocelular, en este trabajo se desarrolló un sistema de expresión de los genes de la proteína del core y la proteína no estructural NS5A del virus, de tres genotipos distintos, mediante la clonación de los mismos y su posterior transfección en líneas celulares de hepatoma. Se obtuvieron buenos niveles de expresión de ambas proteínas, lo que servirá como base para futuras investigaciones.

Palabras clave: hepatitis C, clonación, transfección, core, NS5A.

\section{ABSTRACT}

The hepatitis C virus causes infection in approximately 170 million persons worldwide, and in many of these patients the infection will progress to cirrhosis and hepatocellular carcinoma. Although there have been great advancements in the knowledge of this virus due to the development and optimization of a cell culture system during the past few years, some of the stages of the viral cycle are not completely understood, and many of the functions of the viral proteins still remain unclear. To elucidate the role of two of these 
proteins in the development of hepatocellular carcinoma, an expression system of the genes of core protein and non structural protein NS5A from three different genotypes of HCV was developed, through the cloning of these genes and the further transfection in several hepatoma cell lines. High levels of expression of both proteins were obtained, which will serve useful for future investigations.

Key words: hepatitis C, cloning, transfection, core, NS5A.

\section{INTRODUCCIÓN}

\section{Historia del virus de la hepatitis $C$}

El virus de la hepatitis C (HCV) es el causante de la mayor parte de las hepatitis no A no B, e infecta a unos 170 millones de personas en todo el mundo. La mayoría son infecciones hepáticas crónicas, sin manifestaciones clínicas hasta fases tardías, y en muchos casos hay una evolución a cirrosis y carcinoma hepatocelular. De momento no existe vacuna para prevenir la infección, y el tratamiento, que consiste en la combinación de interferón alfa pegilado y ribavirina, da lugar a la aparición de efectos secundarios y no es bien tolerado en muchos pacientes (Moradpour et al, 2007).

Es un virus de amplia distribución, y de alta prevalencia en África subsahariana, sureste asiático y Extremo Oriente. En España la prevalencia es del 0,5-2\%, mientras que en Egipto puede llegar al 20\%. La principal vía de transmisión es la parenteral, aunque también están descritas la vía sexual y la transmisión vertical (en mujeres inmunodeprimidas) (Esteban et al, 2008).

Los aislados del virus de la hepatitis $\mathrm{C}$ se clasifican en genotipos y subtipos. Existen seis genotipos principales del virus, que difieren en su secuencia de nucleótidos en un 30$35 \%$, y dentro de cada genotipo se definen varios subtipos (denominados a, b, c... y así sucesivamente), que difieren en la secuencia de nucleótidos en un 20-25\%. Los genotipos más frecuentes en España son el 1a, 1b y 3a. Es importante señalar que, dependiendo del genotipo del virus, el paciente muestra una respuesta distinta al tratamiento. Por ejemplo, el genotipo 1 no responde bien a la terapia basada en interferón alfa. En un mismo individuo puede coexistir una gran variedad de genomas del virus, lo que da lugar a una gran heterogeneidad genética que se conoce por el término cuasiespecies (Moradpour et al, 2007).

Este virus fue descubierto en 1989, cuando se aisló del suero de un paciente con hepatitis post-transfusional no A, no B. El estudio y la comprensión de la biología de este virus fueron muy complicados en los primeros años debido a la carencia de un modelo 
apropiado de replicación e infección. Se utilizaron sistemas de expresión heterólogos, clones funcionales de $\mathrm{ADN}$ copia infecciosos in vivo en chimpancés, y también se utilizaron un replicón, pseudopartículas (partículas retrovirales con proteínas de envuelta de HCV funcionales, que permitieron el estudio de los mecanismos de entrada bajo condiciones reproducibles), y más recientemente, cultivos celulares.

Con el desarrollo del sistema de replicón se pudo por primera vez estudiar la replicación del ARN del virus de la hepatitis $\mathrm{C}$ en células de hepatocarcinoma humano, Huh7. Además se pudieron estudiar los elementos del ARN y las proteínas, se pudieron analizar las características bioquímicas y ultraestructurales del complejo de replicación viral, y se facilitó el descubrimiento de fármacos antivirales.

Posteriormente se desarrollaron replicones completos y genomas de HCV que se replicaban eficientemente en cultivos celulares, y se extendió el rango de células huésped a otras líneas celulares, hepáticas y no hepáticas. En estos replicones se observó la aparición de mutaciones adaptativas, que aumentaban la eficiencia de replicación, pero eran incapaces de producir virus infectivo (Moradpour et al, 2007).

No se consiguió su replicación completa en líneas celulares hasta el aislamiento de una cepa de genotipo 2a (denominada JFH-1) a partir de un paciente japonés con hepatitis fulminante (Kato et al, 2006). Esta cepa se replicaba en células Huh-7 y otras líneas celulares sin el requerimiento de mutaciones adaptativas. Los genomas de JFH-1 clonados y transfectados en células Huh-7 producían virus infectivo, lo que permitió el estudio in vitro del ciclo viral completo. Sin embargo, aún hay muchos aspectos que no se conocen bien, el papel que juegan algunas proteínas virales aún ha de ser dilucidado, y se deben desarrollar sistemas robustos para todos los genotipos del virus.

\section{Estructura del virus de la hepatitis $\mathrm{C}$}

El virus de la hepatitis $\mathrm{C}$ es un virus envuelto perteneciente a la familia Flaviviridae, género Hepacivirus, con genoma de ARN monocatenario de polaridad positiva.

$\mathrm{Su}$ visualización es difícil. La partícula vírica tiene un tamaño de 40-70 nm de diámetro, es de simetría helicoidal, y presenta una envoltura lipídica de doble capa, que envuelve la nucleocápsida.

$\mathrm{Su}$ genoma, de 9,6 kb, está constituido por dos regiones no codificantes (NCR) en cada uno de los extremos, y un único marco de lectura (ORF), que da lugar a una única poliproteína de unos 3000 aminoácidos. Esta poliproteína (figura 1) es procesada y da lugar a tres proteínas estructurales (core, E1 y E2), y siete proteínas no estructurales (p7, NS2, NS3, 
NS4A, NS4B, NS5A y NS5B). La proteína core y las glicoproteínas de envuelta E1 y E2 son los principales componentes del virión. Estas dos glicoproteínas están ancladas a una envoltura de doble capa lipídica derivada de la célula huésped, la cual envuelve a la nucleocápsida, compuesta de múltiples copias de la proteína core, y el ARN genómico (Moradpour et al, 2007).

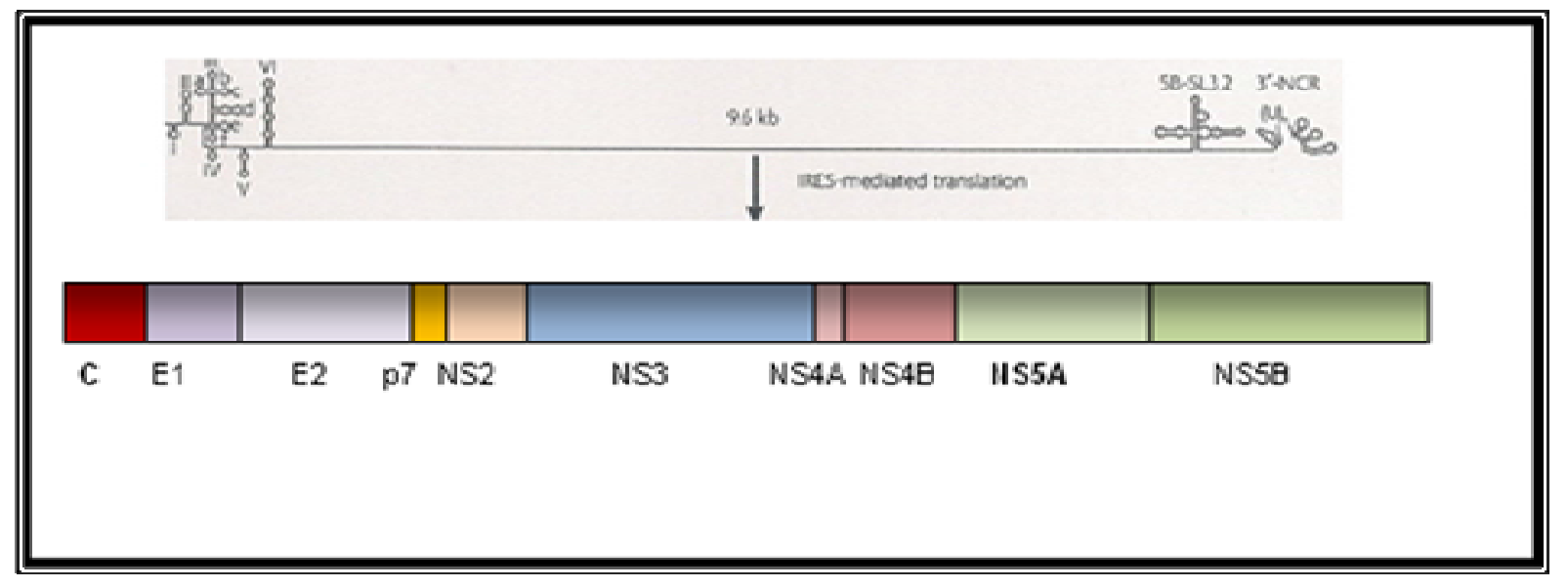

Figura 1: Organización genética de HCV y poliproteína (adaptación de Moradpour et al, 2007. Replication of hepatitis C virus. Nature Rev Microbiol, 5, 453-463, figura 3).

El extremo 5'-NCR del genoma está muy conservado entre los distintos aislados del virus, y presenta un lugar interno de entrada del ribosoma (IRES), que es esencial para la traducción independiente del cap. Está compuesto por 4 dominios, que se designan de I a IV, siendo los dominios I y II esenciales para la replicación. Se ha visto que existe un micro ARN, el miR-122, que incrementa la replicación del ARN viral, siendo éste el primer ejemplo de un virus que utiliza un micro ARN celular y convirtiéndose en una posible diana antiviral, a través de la antagonización de su función.

El extremo 3'-NCR consta de una región corta variable (poli U/UC con unos 80 nucleótidos), y una región casi invariable de 98 nucleótidos llamada cola X. Los elementos conservados son también esenciales para la replicación in vitro e in vivo.

También se ha identificado un elemento de replicación que actúa en cis, denominado CRE, en la secuencia que codifica la región C-terminal de NS5B.

Brevemente, las funciones de las proteínas virales son las siguientes:

- Proteína core: es la que forma la nucleocápsida. Esta proteína podría tener un papel importante en la replicación y en la morfogénesis de HCV. Interacciona con gotas lipídicas, y 
esto podría afectar al metabolismo de los lípidos, ocasionando el desarrollo de esteatosis hepática que se ve con frecuencia en pacientes con hepatitis $\mathrm{C}$.

- Proteínas de envuelta E1 y E2: están glicosiladas y forman un complejo no covalente que sería la unidad que forma la envoltura, y junto al core son los principales componentes de la partícula vírica. Estas dos proteínas se anclan a la envoltura lipídica que rodea la nucleocápsida, e interaccionan con los glucosaminoglucanos de la membrana celular, participando en la unión inicial del virus al hepatocito, que es su principal célula diana. Los dominios transmembrana de E1 y E2, localizados en el extremo C-terminal, están implicados en la heterodimerización y tienen propiedades de retención del retículo endoplásmico.

- Proteína p7: es un polipéptido de 63 aminoácidos esencial para la infección productiva in vivo. Forma oligómeros y tiene actividad de canal catiónico, por lo que es muy posible que pertenezca a la familia de las viroporinas, con un papel muy importante en la maduración y liberación del virus. Podría ser una buena diana antiviral.

- NS2-3: es una auto-proteasa, en concreto una cisteína-proteasa que corta entre las proteínas NS2 y NS3 durante el procesamiento de la poliproteína. Es esencial para que haya replicación in vitro e in vivo. La actividad catalítica reside en la mitad C-terminal de NS2 y el tercio N-terminal de NS3. Como todas las proteínas de HCV, se asocia con membranas intracelulares.

- NS3/4A: NS3 es una proteína multifuncional, con actividad serina-proteasa localizada en el tercio N-terminal, que se activa gracias a la interacción con NS4A, y también tiene actividad ARN helicasa/NTPasa localizada en los dos tercios C-terminales. Este complejo es una de las principales dianas de inhibidores.

- NS4B: es una proteína de $27 \mathrm{kD}$ que induce la formación de la red membranosa, pero su función no se conoce muy bien. La red membranosa (también llamada complejo replicativo) es una estructura que se forma durante la replicación del virus, compuesta de membranas del retículo endoplásmico y gotas lipídicas, donde el ARN viral se amplifica.

- NS5A: es una fosfoproteína que puede encontrarse en dos formas: basalmente fosforilada o hiperfosforilada. Probablemente el estado de fosforilación modula la eficiencia de la replicación.

- NS5B: es la ARN polimerasa-ARN dependiente (RdRp). Es otra de las principales dianas antivirales. Contiene motivos que son compartidos por todas las RdRp's, y posee la estructura típica de mano derecha, con dedos, palma y pulgar.

Además se ha identificado un marco de lectura alternativo en la región codificante de la proteína core, llamado ARF, en el genotipo 1a, que tiene el potencial de codificar una 
proteína de hasta 160 aminoácidos denominada ARFP o proteína F. En pacientes con hepatitis $\mathrm{C}$ se han detectado anticuerpos y linfocitos $\mathrm{T}$ específicos de la proteína $\mathrm{F}$, lo que sugiere que esta proteína se expresa durante la infección de HCV. Sin embargo, no es necesaria para la replicación in vivo o in vitro. Todavía se desconoce su función. (Moradpour et al, 2007).

\section{Ciclo de replicación del virus de la hepatitis $\mathrm{C}$}

El virus de la hepatitis $\mathrm{C}$ circula en el hospedador en varias formas: puede ir asociado a lipoproteínas de baja densidad (LDL) y muy baja densidad (VLDL), representando ambas formas la fracción infectiva, y también puede circular como virión unido a inmunoglobulinas o como virión libre.

Solamente infecta a humanos y a chimpancés. Los hepatocitos son su principal célula diana, pero también puede infectar linfocitos $\mathrm{B}$, células dendríticas y otros tipos celulares. Se han propuesto como receptores el CD81 (que se encuentra en la superficie de muchas células, incluidas los hepatocitos), el receptor LDL (LDLR), el receptor de fagocito clase B tipo I (SR-BI), la claudina-1, y más recientemente, la ocludina (Moradpour et al, 2007; Bartenschlager et al, 2010). La proteína E2 también es capaz de unirse a DC-SIGN y L-SIGN. L-SIGN es una lectina calcio-dependiente que se expresa en las células endoteliales sinusoides hepáticas, que puede que facilite el proceso de infección atrapando al virus para su interacción con los hepatocitos.

Junto con los glucosaminoglucanos, el LDLR y otras proteínas de superficie implicadas en la unión a lipoproteínas séricas y en el metabolismo podrían servir como recolectores de partículas virales para su futura interacción con CD81 y otros componentes de los receptores. Tanto CD81 como SR-BI se unen a E2, y son necesarios pero no suficientes para la entrada de $\mathrm{HCV}$, lo que sugiere que se requieren otros factores específicos de hepatocitos.

La claudina-1 se ha identificado como correceptor. Es esencial para la entrada de HCV en los hepatocitos y convierte a determinadas células no hepáticas en permisivas a la infección. Se sabe que actúa en una fase tardía del proceso de entrada, después de la unión e interacción de HCV con CD81.

La entrada se produce por endocitosis mediada por clatrina. La partícula viral queda englobada en un endosoma. La disminución del $\mathrm{pH}$ provoca un cambio conformacional en las glicoproteínas del virus, lo que lleva a la fusión de la membrana viral con la membrana del endosoma, produciéndose la liberación de la partícula viral desnuda. 
La traducción se inicia a través del IRES, constituido por los dominios II, III y IV del extremo 5'-NCR y los primeros 20-40 nucleótidos de la región del core. Se forma un complejo binario entre el IRES y la subunidad 40S del ribosoma, seguido del ensamblaje de un complejo parecido a la subunidad 48S al codón de iniciación. Está implicado un factor de iniciación de la traducción eucariótico (1IF3). Se forma una poliproteína que se procesa por proteasas virales y celulares (Moradpour et al, 2007).

Los detalles de la replicación no se conocen bien, pero se ha propuesto que después de la traducción y el corte de la poliproteína, las proteínas nuevas interaccionan entre ellas para formar un complejo replicativo llamado replisoma, el cual utiliza la cadena positiva de ARN como molde para sintetizar una cadena negativa de ARN, el cual a su vez sirve como molde para sintetizar más cadenas positivas que son traducidas a poliproteína, o bien se empaquetan. Parece ser que las proteínas no estructurales forman un complejo de replicación asociado a membranas, que compartimentaliza la producción de proteínas virales y ARN. No está claro cómo el ARN se organiza dentro del replisoma, pero hay evidencias de que la replicación utiliza preferentemente un mecanismo en cis. Además, estos complejos replicativos pueden tener una función importante en la protección del ARN viral de doble cadena frente a las defensas del huésped o los fenómenos de interferencia, además de proveer de lípidos importantes para la replicación (Tong y Malcolm, 2005).

El ensamblaje tiene lugar cerca de gotas lipídicas, en las que se va acumulando la proteína core. Se piensa que el ARN viral es transportado desde los sitios de replicación a las gotas lipídicas mediante la replicasa viral. La proteína NS5A, que tiene una capacidad intrínseca de unirse al ARN, podría liberarse del complejo replicativo a la superficie de las gotas lipídicas. Podría haber una interacción core-NS5A que llevaría al transporte de ARN a la proteína core, desencadenando la formación de la nucleocápsida (Bartenschlager et al, 2010).

Las etapas tardías del ciclo viral son poco conocidas. Se cree que los viriones salen por gemación del retículo endoplásmico o algún compartimento derivado del mismo, proceso que estaría ligado a la síntesis de VLDL, y salen de la célula a través de la ruta secretoria.

\section{Importancia de las proteínas core y NS5A}

La proteína del core es la proteína del virus de la hepatitis $\mathrm{C}$ más conservada. Hay una serie de residuos casi idénticos en la región C-terminal del genoma. Se sabe que es un componente esencial de la partícula viral infecciosa, sin embargo muchos aspectos de su función aún no se conocen bien. Durante el ensamblaje esta proteína es procesada por dos 
proteasas celulares (procesamiento que también se da en otras proteínas core de otros virus de la familia Flaviviridae). Primero se produce un corte por una peptidasa que da lugar a una proteína core inmadura de 191 aminoácidos, la cual es procesada nuevamente dando lugar a la proteína core madura, de 173-179 aminoácidos y $21 \mathrm{kD}$. Parece ser que el corte que produce la segunda de esas enzimas (llamada SPP, signal peptide peptidase) es esencial para que el core se movilice al interior de gotas lipídicas, que como ya se ha visto, son muy importantes en el ensamblaje y la diseminación del virus. Se ha visto que si la actividad de SPP está impedida, se produce una disminución del título infeccioso (Kopp et al, 2009).

Al menos 177 residuos del core son esenciales para producir partículas infecciosas, pero cambios en los últimos 14 residuos no bloquean el procesamiento de la región core-E1. Se necesitan múltiples mutaciones en esta región para inhibir el corte de SPP y la producción de virus infeccioso. Aún no se sabe con certeza por qué algunos aminoácidos están altamente conservados, pero se ha visto que la sustitución puntual de algunos aminoácidos en la región 170-177 impide la producción de virus infeccioso (Kopp et al, 2009). Además, se ha visto que las mutaciones de los aminoácidos 70 y 91 del core están asociadas a la respuesta al tratamiento con interferón.

La proteína no estructural NS5A es una fosfoproteína de 447 aminoácidos que juega un papel muy importante en el ciclo vital del virus de la hepatitis C. NS5A se ancla a la membrana por una $\alpha$-hélice anfipática N-terminal, constituida por una parte hidrofóbica, rica en triptófano, embebida en la cara citosólica de la membrana, mientras que la parte polar es expuesta hacia el citosol y está probablemente implicada en interacciones específicas proteína-proteína, que son esenciales para la formación de los complejos replicativos funcionales de $\mathrm{HCV}$.

$\mathrm{Su}$ capacidad de unirse a moléculas de ARN ha sido confirmada bioquímicamente. Existe una hipótesis según la cual múltiples dímeros de NS5A podrían formar una matriz bidimensional en membranas intracelulares, creando una especie de raíl por el que se podría deslizar el ARN. Otras regiones de NS5A lo protegerían de la degradación por ARNasas celulares o del reconocimiento por mecanismos de defensa viral contra ARN de doble cadena. Según este modelo, NS5A ataría el ARN viral en las membranas intracelulares y coordinaría las distintas fases de la replicación. Se ha visto que en una célula infectada se produce un exceso de proteínas no estructurales, y sólo en una pequeña proporción están activamente dedicadas a la replicación de $\mathrm{HCV}$, por lo que se piensa que esta acumulación podría ser importante para antagonizar las rutas antivirales innatas celulares previas al inicio de la replicación de HCV (Moradpour et al, 2007). 
Además, como ya se ha mencionado, la proteína NS5A se puede encontrar en estado basalmente fosforilado o hiperfosforilado. La isoforma alfa de la kinasa CKI podría ser responsable de esta fosforilación, aunque podría haber más kinasas celulares implicadas en la generación de las distintas formas de NS5A. Esta fosforilación se da también en otros hepacivirus y pestivirus, y también se da en la proteína NS5 de los flavivirus, por lo que se cree que podría tener un papel fundamental en el ciclo vital del virus. La hiperfosforilación de NS5A reduce la interacción con la proteína A unida a la proteína de membrana unida a vesículas humanas, la cual está implicada en dirigir a las proteínas no estructurales a balsas de lípidos que podrían estar implicados en la replicación de virus ARN (Moradpour et al, 2007).

Los individuos infectados con el virus de la hepatitis $\mathrm{C}$ presentan un elevado riesgo de desarrollar cirrosis hepática y carcinoma hepatocelular. El tratamiento consiste en la combinación de inyecciones semanales de interferón alfa pegilado y la administración oral de ribavirina dos veces al día, en periodos que varían de 24 a 72 semanas dependiendo del genotipo. Sin embargo, los efectos adversos asociados a este régimen terapéutico suponen un peso fisiológico y psicológico significativo en el paciente. Además, la respuesta virológica sostenida en los pacientes infectados con el genotipo 1 suele ser menor del 50\%, lo que evidencia la necesidad de desarrollar nuevas terapias, como por ejemplo los inhibidores de la NS3-proteasa y la NS5B-polimerasa. En este punto conviene señalar que también se están estudiando inhibidores de NS5A, como el compuesto BMS-790052, el cual ha demostrado una buena eficacia frente a gran número de genotipos de $\mathrm{HCV}$ en estudios in vitro y en ensayos clínicos en fase I de pacientes crónicamente infectados por HCV. Este tipo de inhibidores podría tener en el futuro un papel importante en el tratamiento sin interferón (Gao et al, 2010).

Por último, se ha visto en un estudio reciente que NS5A podría estar implicada en la resistencia a interferón alfa que desarrollan algunos pacientes. En este estudio se seleccionó un clon resistente a este fármaco mediante tratamiento prolongado de células Huh 7.5 a bajas dosis de interferón alfa, y se identificaron cuatro mutaciones en el extremo C-terminal de la secuencia de NS5A en ese clon. Introduciendo esas cuatro mutaciones en virus salvaje de la cepa JFH-1, se conseguía establecer un clon de HCV resistente (Huong et al, 2010).

\section{Objetivos del presente trabajo}

En un estudio reciente que se está llevando a cabo en colaboración entre el Centro de Biología Molecular Severo Ochoa, el Instituto de Investigaciones Biomédicas Alberto Sols de la UAM, y el Hospital Carlos III, se ha visto que el virus de la hepatitis C influye en la 
fosforilación de la serina 10 de la histona 3, lo que determina la activación transcripcional de varios genes.

Este hecho podría estar relacionado con el desarrollo de carcinoma hepatocelular que se da en muchos pacientes infectados por el virus de la hepatitis C. Este tumor es el más común dentro de los tumores hepáticos, y se han descrito varios factores medioambientales y estilos de vida como posibles factores de riesgo en el desarrollo de esta enfermedad, uno de los cuales es la infección por el virus de la hepatitis $\mathrm{C}$.

Recientes estudios de epigenética han identificado un gran número de genes y rutas que podrían estar implicadas en la evolución a carcinoma hepatocelular, en concreto se ha visto que se producen cambios en la metilación del ADN, alteraciones en las histonas y en el silenciamiento de genes mediado por ARN (Herceg y Paliwal, 2011).

Las histonas forman parte de los nucleosomas, unidad estructural básica de la cromatina, compuesta por proteínas no histónicas, y las histonas (H2A, H2B, H3 y H4). Las histonas pueden sufrir modificaciones (fosforilación, acetilación, desaminación, ubiquitinización, metilación e isomerización de prolinas), y estas modificaciones pueden determinar si un gen está activado o silenciado. La serina en posición 10 de la histona 3 juega un papel fundamental en la condensación de la cromatina y en la progresión del ciclo celular, y su fosforilación influye en la activación de determinados genes. En células infectadas por el virus de la hepatitis $\mathrm{C}$, esta fosforilación está disminuida.

Se quiere investigar qué proteínas virales estarían implicadas en esta regulación génica, y dada la importancia y las características de la proteína core y la proteína NS5A, ambas fueron seleccionadas para el inicio de la investigación.

Los objetivos fueron:

- Clonación de los genes que codifican la proteína core y la proteína NS5A del virus de la hepatitis $\mathrm{C}$ de los genotipos 1a, 1b y 2a (cepas H77, Con1 y Jc1 respectivamente), utilizando para ello el vector de expresión pCMV-HA.

- Transfección en células 293T (fibroblastos de riñón humano).

- Transfección en células de hepatoma Huh 7.5 reporter.

- Comprobar la expresión de proteínas mediante Western blot.

- Optimizar la transfección en células Huh 7.5 reporter. 


\section{MATERIAL Y MÉTODO}

\section{Clonación de los genes de las proteínas core y NS5A de HCV}

El proyecto se inició con la clonación de los genes de interés, en este caso los genes que codifican las proteínas core y NS5A del virus de la hepatitis C. Para ello se partió de la cepa Jc1, de genotipo 2a, aunque posteriormente también se utilizaron las cepas H77, de genotipo 1a, y la cepa Con1, de genotipo $1 \mathrm{~b}$.

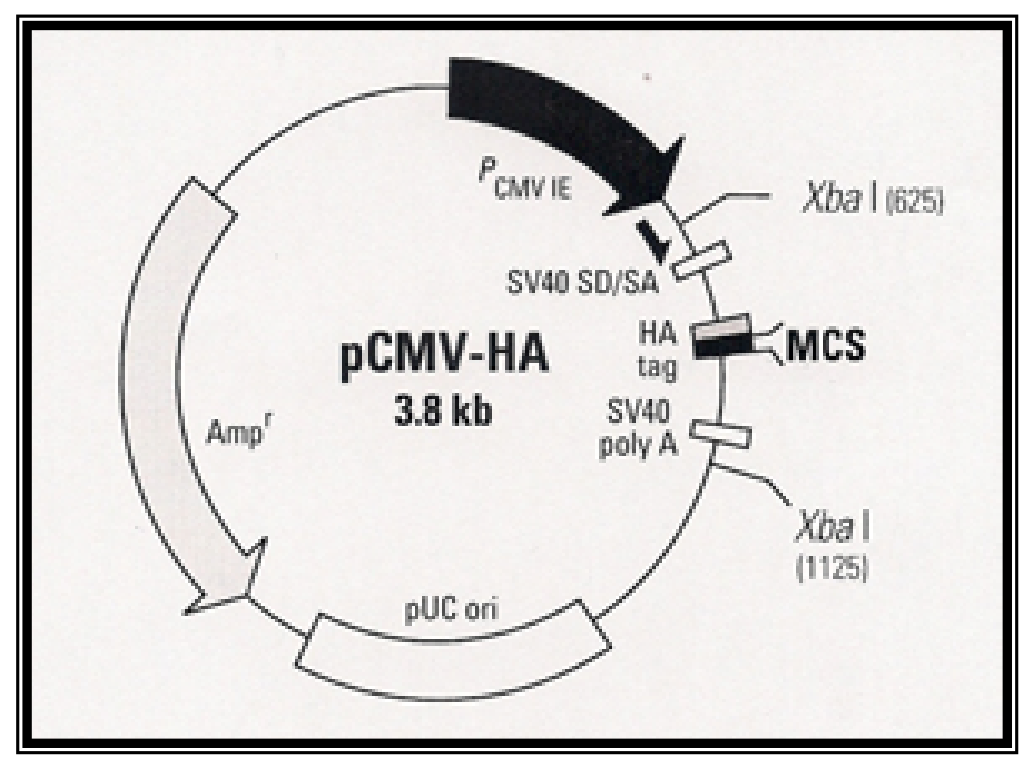

Figura 2: Esquema del vector de expresión pCMV-HA.

Dichos genes se insertaron, por separado, en el vector pCMV-HA (Clontech Laboratories, Inc.) (figura 2). Éste es un vector de expresión que contiene un promotor temprano del citomegalovirus humano $\left(\mathrm{P}_{\mathrm{CMV}} \mathrm{IE}\right)$; un intrón derivado de SV40 (donador/aceptor de splicing, SV40 SD/SA); un tag con el epítopo de hemaglutinina como marcador (HA tag); una señal de poliadenilación de SV40 (SV40 poly A); y un sitio de clonación múltiple o MCS (multiple cloning site), en el cual se inserta el gen de interés. También hay un gen de resistencia a ampicilina que permitirá su selección en bacterias Escherichia coli $\left(\mathrm{Amp}^{\mathrm{r}}\right)$.

Previamente a la inserción de los genes, éstos se amplificaron por PCR. Se seleccionaron como sitios de restricción los correspondientes a las enzimas de restricción EcoRI y BglII. Los cebadores utilizados para cada una de las cepas fueron: 
- Jc1:

- NS5A:

5'- TTTATACGAATTCGCTCCGGATCCTGGCTCCGCGACG

3'- TTTATAAGATCTTCAGCAGCACACGGTGGTATCGTCCTCC

- Core:

5' - TATTTAAGGAATTCAAATGAGCACAAATCCTAAACCTC

3'-AAATTAAGAGATCTTTAAGCGGAGACCGGGGTGGTGATGC

- H77:

- NS5A:

5' - ATTTAAGAATTCAATCCGGTTCCTGGCTAAGGGA

3' - ATTTAAAGATCTTCAGCAGCACACGACATCTTCCG

- Core:

5' - ATTTAAGAATTCAAATGAGCACGAATCCTAAACC

3' - ATTTAAAGATCTTTAGGCTGAAGCGGGCACAGTCA

- Con1.

- NS5A:

5' - ATTTAAGAATTCAATCCGGCTCGTGGCTAAGAGAT

3' - ATTTAAAGATCTTCAGCAGCAGACGACGTCCCTCAC

- Core:

5' - ATTTAAGAATTCAAATGAGCACGAATCCTAAACC

3' - ATTTAAAGATCTTTAAGCGGAAGCTGGGATGGTCA

Una vez diseñados los cebadores se pidieron a un laboratorio (Roche Applied Science, Barcelona).

En la mayoría de los protocolos utilizados en este trabajo se utilizó una ADN polimerasa Taq de alta fidelidad (procedente de la bacteria Thermus aquaticus, de Roche), y se programaron 25 ciclos para cada PCR, con los siguientes cambios de temperatura:

$-94^{\circ} \mathrm{C} 2$ minutos.

$-94^{\circ} \mathrm{C} 30$ segundos.

- $60^{\circ} \mathrm{C} 30$ segundos (temperatura de hibridación).

$-72^{\circ} \mathrm{C} 35$ segundos.

25 ciclos

$-72^{\circ} \mathrm{C} 5$ minutos.

- Mantenimiento a $4^{\circ} \mathrm{C}$. 
Los reactivos que se utilizaron en cada una de las reacciones de PCR se especifican en la tabla 1.

El resultado de la PCR se visualizó mediante electroforesis en gel de agarosa al 1\% con bromuro de etidio, utilizando el marcador $\Phi 29$, comprobando en cada caso que las bandas amplificadas se correspondían con el tamaño esperado: 580 bp para el gen del core, 1400 bp para el gen de NS5A, y 3800 bp para el plásmido pCMV-HA.

\begin{tabular}{|l|c|c|c|}
\hline REACTIVO & CONCENTRACIÓN & MUESTRA & CONTROL NEGATIVO \\
\hline Cebador F & $50 \mathrm{ng} / \mathrm{ml}$ & $1 \mu 1$ & $1 \mu \mathrm{l}$ \\
\hline Cebador R & $50 \mathrm{ng} / \mathrm{ml}$ & $1 \mu 1$ & $1 \mu \mathrm{l}$ \\
\hline 10x Buffer & & $5 \mu 1$ & $5 \mu 1$ \\
\hline dNTP's & $10 \mu \mathrm{M}$ & $1 \mu 1$ & $1 \mu \mathrm{l}$ \\
\hline Polimerasa Taq & $3300 \mathrm{unid} / \mathrm{ml}$ & $0,75 \mu \mathrm{l}$ & $0,75 \mu \mathrm{l}$ \\
\hline Agua & & $40,75 \mu \mathrm{l}$ & $40,75 \mu \mathrm{l}$ \\
\hline ADN (Jc1, H77 o Con1) & $100 \mathrm{ng} / \mathrm{ml}$ & $0,5 \mu 1$ & - \\
\hline TOTAL & & $\mathbf{5 0} \boldsymbol{\mu l}$ & $\mathbf{4 9 , 5} \boldsymbol{\mu l}$ \\
\hline
\end{tabular}

Tabla 1: Reactivos de PCR.

Una vez obtenidas las bandas de $\mathrm{ADN}$ se procedió a la purificación de dichas bandas a partir del gel de agarosa, utilizando el kit comercial "QIAquick gel extraction kit" (QIAgen), siguiendo las instrucciones del fabricante.

Posteriormente se procedió a la digestión del plásmido pCMV-HA y los genes purificados con las enzimas de restricción EcoRI y BgIII. Los reactivos utilizados en esta reacción se especifican en la tabla 2. La cantidad de ADN en los tres casos fue de $1 \mu \mathrm{g}$.

\begin{tabular}{|l|c|c|c|}
\hline REACTIVO & NS5A & CORE & PLÁSMIDO \\
\hline EcoRI & $1 \mu 1$ & $1 \mu 1$ & $1 \mu 1$ \\
\hline BglII & $1 \mu 1$ & $1 \mu 1$ & $1 \mu 1$ \\
\hline $10 x$ Buffer 3 & $10 \mu \mathrm{l}$ & $10 \mu \mathrm{l}$ & $10 \mu 1$ \\
\hline Agua & $45 \mu 1$ & $72,3 \mu 1$ & $84 \mu 1$ \\
\hline ADN $(1 \mu \mathrm{g})$ & $43 \mu 1$ & $15,7 \mu 1$ & $3 \mu 1$ \\
\hline Fosfatasa alcalina & - & - & $1 \mu 1$ \\
\hline TOTAL & $\mathbf{1 0 0} \boldsymbol{\mu l}$ & $\mathbf{1 0 0} \boldsymbol{\mu l}$ & $\mathbf{1 0 0} \boldsymbol{\mathbf { l }}$ \\
\hline
\end{tabular}

Tabla 2: Reactivos de digestión. 
Después se ligó cada uno de los genes con el plásmido pCMV-HA, utilizando para ello la enzima T4 ligasa (New England Biotechnology), en una proporción 3:1 del plásmido en relación al gen que se insertó. Se incubó a $16^{\circ} \mathrm{C}$ durante 24 horas. En la tabla 3 se especifican los reactivos de ligación.

Una vez obtenidas las ligaciones, se mezclaron con una alícuota de bacterias competentes pertenecientes a la cepa DH5 $\alpha$ de Escherichia coli y se incubaron en hielo durante 30 minutos. Una vez realizada la mezcla, se les sometió a un choque térmico, a una temperatura de $42^{\circ} \mathrm{C}$ durante 30 segundos, con el fin de producir un aumento en la permeabilidad de la membrana bacteriana mediante la apertura de los poros y facilitando así la incorporación del ADN. Luego se añadió medio SOC y se incubó a $37^{\circ} \mathrm{C}$ durante una hora en agitación. Finalmente se sembraron en agar compuesto de medio LB con ampicilina y se incubaron en estufa a $37^{\circ} \mathrm{C}$ durante 24 horas.

\begin{tabular}{|l|c|c|c|}
\hline REACTIVO & VECTOR + NS5A & VECTOR + CORE & PLÁSMIDO SOLO \\
\hline T4 ligasa & $0,5 \mu 1$ & $0,5 \mu 1$ & $0,5 \mu 1$ \\
\hline $10 \times$ Buffer & $1 \mu 1$ & $1 \mu 1$ & $1 \mu 1$ \\
\hline pCMV x10 & $1,3 \mu 1$ & $4,2 \mu 1$ & $4,2 \mu 1$ \\
\hline NS5A & $7,2 \mu 1$ & - & - \\
\hline Core & - & $4,2 \mu 1$ & $4,2 \mu 1$ \\
\hline Agua & - & - & $\mathbf{9 , 9} \boldsymbol{l}$ \\
\hline TOTAL & $\mathbf{1 0} \boldsymbol{\mu l}$ & $\mathbf{9 , 9} \boldsymbol{\mu l}$ & \\
\hline
\end{tabular}

Tabla 3: Reactivos utilizados en la ligación del plásmido con cada inserto.

Una vez transcurrido este tiempo se realizaron múltiples PCR's de un gran número de las colonias que habían crecido para identificar cuáles de ellas habían incorporado el gen de interés. Estas colonias se cultivaron en medio LB con ampicilina y se extrajo el ADN plasmídico mediante la realización de minipreps siguiendo el protocolo del "Wizard Plus SV Minipreps DNA Purification System" (Promega). Todas las muestras se enviaron a secuenciar al laboratorio Macrogen y las secuencias se compararon con la secuencia consenso para determinar si se habían producido mutaciones y si éstas eran o no sinónimas. Se seleccionaron los mejores clones para la transfección.

\section{Transfección de los genes core y NS5A en líneas celulares}

Con el fin de extraer el ADN de las muestras se realizaron unas maxipreps siguiendo el protocolo del "PureLink ${ }^{\mathrm{TM}}$ Hipure Plasmid Filter Purification Kit" (Invitrogen). 
Para la primera transfección se utilizaron tres líneas celulares estables: células Huh 7.5 (células de hepatoma humano); células Lunet (un clon derivado de células Huh 7.5 altamente permisivo a la infección por HCV); y células Huh 7.5 reporter, que son células Huh 7.5 que llevan dos marcadores: la proteína GFP, que se localiza en la mitocondria, y la proteína RFP, que cuando no hay infección se localiza en la mitocondria, pero cuando hay infección se localiza en el núcleo, debido a un corte producido por la proteína NS3/4A del virus (Jones et al, 2010). Esta primera transfección se llevó a cabo mediante electroporación. Se tomó $1 \mu \mathrm{g}$ de cada muestra, y se mezcló con cada línea celular después de su tripsinización, centrifugación, contaje celular y resuspensión con medio DMEM + suero fetal bovino (FCS) al $10 \%$ de modo que la concentración final fuera de $5 \times 10^{6}$ células $/ \mathrm{ml}$. Se aplicó un pulso con un voltaje de 260 voltios y una capacitancia de 950 microfaradays. El electroporador utilizado fue el Gene Pulser XCell Electroporation System, de Bio-Rad. Se traspasó cada una de las muestras a tubos falcon con $4 \mathrm{ml}$ de medio DMEM + FCS al 10\% y se repartió en placas de $35 \mathrm{~mm}$ para incubar a $37^{\circ} \mathrm{C}$ durante 5 horas. Luego se hizo un lavado con PBS para eliminar células muertas y se incubó durante 48 horas antes de proceder a la lisis celular.

Como este método no dio buenos resultados se repitió la transfección utilizando el reactivo FuGENETM HD (Promega), basado en lípidos, en una proporción reactivo:ADN de 3:1 (se pusieron $6 \mu \mathrm{l}$ de reactivo por cada $2 \mu \mathrm{g}$ de ADN). Una vez hecha la mezcla de reactivo, ADN y medio (DMEM + FCS al 10\%), se dejó a temperatura ambiente durante 15 minutos y se distribuyó en gotas por cada una de las placas con medio de cultivo. Se incubó a $37^{\circ} \mathrm{C}$ durante 48 horas. En este caso se utilizó en primer lugar la línea celular 293T (fibroblastos de riñón humano), ya que son células en las que la transfección es muy eficiente, a una concentración de $1-2 \times 10^{5}$ células/ml y a una confluencia del 40-60\%. Se utilizó como control positivo una placa de células $293 \mathrm{~T}$ a la que se transfectó plásmido GFP, el cual contiene el gen de la proteína verde fluorescente. Transcurridas 72 horas desde la transfección se procedió a la lisis celular, mediante la adición de $300 \mu \mathrm{l}$ de buffer de ruptura/pocillo (de placa M6). El lisado se transfirió a tubos Eppendorf y se mantuvieron a $-20^{\circ} \mathrm{C}$ hasta la realización del Western blot.

Finalmente se repitió el proceso en células Huh 7.5 reporter, ya que la línea celular de hepatoma humano es la que se utiliza con mayor frecuencia en los experimentos con el virus de la hepatitis C. En este caso se transfectó una cantidad de $2 \mu \mathrm{g}$ de ADN también a una proporción 3:1 de reactivo:ADN. El lisado de las células tuvo lugar a las 72 horas de la transfección. 
Para optimizar la transfección se realizó un nuevo experimento en células Huh 7.5 reporter, que consistió en la transfección del plásmido GFP utilizando distintos ratios de ADN y reactivo FuGENETM , para luego comprobar mediante microscopía de fluorescencia con cuál de ellos se obtenía un mayor porcentaje de células transformadas. Se sembraron tres pocillos de una placa M24 con $500 \mu 1$ de medio DMEM + FCS al 10\% con células Huh 7.5 reporter a una concentración de $5 \times 10^{4}$ células/pocillo. Se incubó en estufa a $37^{\circ} \mathrm{C}$ durante 24 horas y luego se procedió a la transfección con reactivo $\mathrm{FuGENE}^{\mathrm{TM}}$ a los proporciones que se indican en la tabla 4.

\begin{tabular}{|l|c|c|c|}
\hline POCILLOS & FUGENE & pGFP & RATIO \\
\hline Pocillo 1 & $0,3 \mu 1$ & $0,2 \mu \mathrm{g}$ & $3: 2$ \\
\hline Pocillo 2 & $0,6 \mu \mathrm{l}$ & $0,2 \mu \mathrm{g}$ & $3: 1$ \\
\hline Pocillo 3 & $1,2 \mu \mathrm{l}$ & $0,2 \mu \mathrm{g}$ & $6: 1$ \\
\hline
\end{tabular}

Tabla 4: Optimización de la transfección.

\section{Expresión de proteínas: Western blot}

Tras la lisis celular se sometió a las muestras de proteínas a una electroforesis en gel de poliacrilamida SDS-PAGE (en condiciones desnaturalizantes).

Para las muestras procedentes de la electroporación se utilizaron unos soportes de pequeño tamaño de Bio-Rad, y se prepararon tres geles de poliacrilamida al $15 \%$ (gel separador) (tabla 5).

\begin{tabular}{|l|l|}
\hline GEL SEPARADOR & $\mathbf{1 5 \%}$ \\
\hline Agua & $1,767 \mathrm{ml}$ \\
\hline Acrilamida $40 \%$ & $1,87 \mathrm{ml}$ \\
\hline $1,5 \mathrm{M}$ Tris $\mathrm{pH} 8,8$ & $1,25 \mathrm{ml}$ \\
\hline SDS $10 \%$ & $0,05 \mathrm{ml}$ \\
\hline TEMED & $0,005 \mathrm{ml}$ \\
\hline APS $10 \%$ & $0,05 \mathrm{ml}$ \\
\hline
\end{tabular}

\begin{tabular}{|l|l|}
\hline GEL CONCENTRADOR & $\mathbf{4} \%$ \\
\hline Agua & $0,95 \mathrm{ml}$ \\
\hline Acrilamida $30 \%$ & $0,5 \mathrm{ml}$ \\
\hline $0,5 \mathrm{M}$ Tris $\mathrm{pH} 6,8$ & $0,5 \mathrm{ml}$ \\
\hline SDS $10 \%$ & $0,02 \mathrm{ml}$ \\
\hline TEMED & $0,0025 \mathrm{ml}$ \\
\hline APS $10 \%$ & $0,025 \mathrm{ml}$ \\
\hline
\end{tabular}

Tabla 5: Composición del gel de poliacrilamida Tabla 6: Composición del gel concentrador

Se rellenaron los soportes, se añadió un poco de etanol para alinear bien el gel y se dejó solidificar. Luego se retiró el etanol y se añadió el gel concentrador (tabla 6), introduciendo el peine. Una vez solidificado este segundo gel, se retiró el peine y se cargaron los pocillos con $20 \mu \mathrm{l}$ de cada muestra tras su calentamiento a $99^{\circ} \mathrm{C}$ durante 5 minutos. Seguidamente se realizó la electroforesis en una cubeta vertical a 200 voltios durante 20 minutos. La transferencia del gel de poliacrilamida a la membrana de nitrocelulosa se hizo en cámara fría a 100 voltios durante 20 minutos. Después se saturó la membrana de nitrocelulosa 
durante una hora a temperatura ambiente con blocking buffer (PBS-Tween al 5\% de leche en polvo). Se hizo un lavado con PBS-Tween al 0,2\% y se incubó con el primer anticuerpo, en este caso el anti-core (proporción 1:500, Santa Cruz Biotechnology), el anti-actina (proporción 1:1000, Sigma) y el anti-HA (proporción 1:500, Biotin Labeled Antibody, HA.11, Covance). Se incubó toda la noche a $4^{\circ} \mathrm{C}$. Al día siguiente, después de tres lavados con PBS-Tween al 0,2\% de diez minutos cada uno, se incubó con el segundo anticuerpo, de cabra anti-ratón, marcado con peroxidasa (proporción 1:10000, Pierce).

Por último se procedió al revelado del Western blot mediante el reactivo ECL (ECL Western Blotting Detection Reagents, Amersham), dejándolo actuar un minuto en cada membrana y colocando luego ésta en un chasis con una placa radiográfica, con distintos tiempos de exposición (1, 3 y 20 minutos).

Para estas células también se realizó una tinción inmunológica con anticuerpo anticore para evidenciar la expresión de proteína.

Para las muestras en las que se utilizó el reactivo FuGENE ${ }^{\mathrm{TM}}$ para la transfección, se realizó un Western blot con soportes de mayor tamaño. El proceso fue básicamente el mismo, con la diferencia de que la electroforesis se hizo a 125 voltios, y la transferencia de proteínas a la membrana de nitrocelulosa se hizo a $200 \mathrm{~mA}$ durante toda la noche. En este caso no se utilizó anticuerpo anti-HA. Las proporciones de los distintos anticuerpos fueron: anti-actina 1:1000; anti-core 1:200; y anti-NS5A 1:500. La incubación de este primer anticuerpo fue de dos horas en agitación. Después de tres lavados con PBS-Tween, se incubó el segundo anticuerpo (que fue el mismo y a la misma proporción), durante una hora.

\section{RESULTADOS}

\section{Identificación de clones transformados}

Para el gen de NS5A resultaron positivas las colonias 8, 11 y 14 (figura 3).

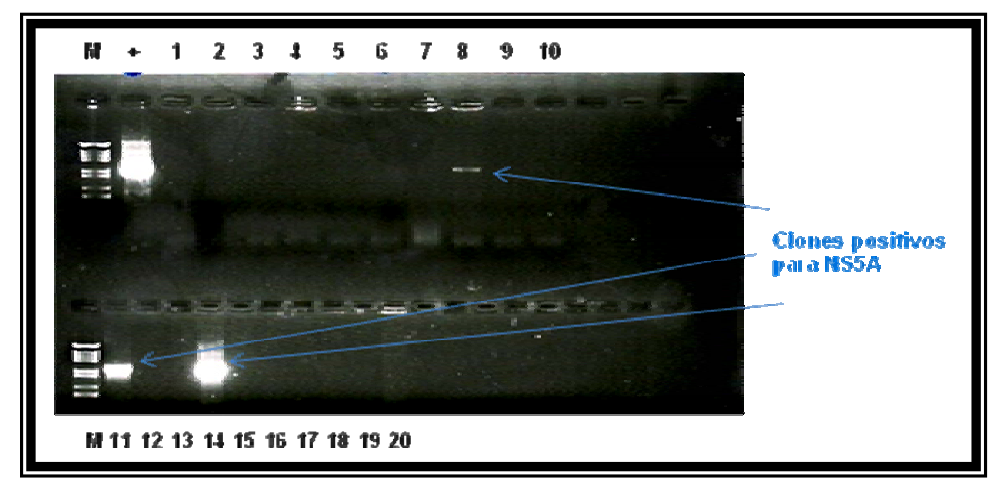


Figura 3: Electroforesis en gel de agarosa para identificar las colonias que han integrado el fragmento de ADN correspondiente al gen NS5A.

Para el gen core se obtuvieron las colonias 3, 5, 6, 8, 12 y 14 (figura 4).

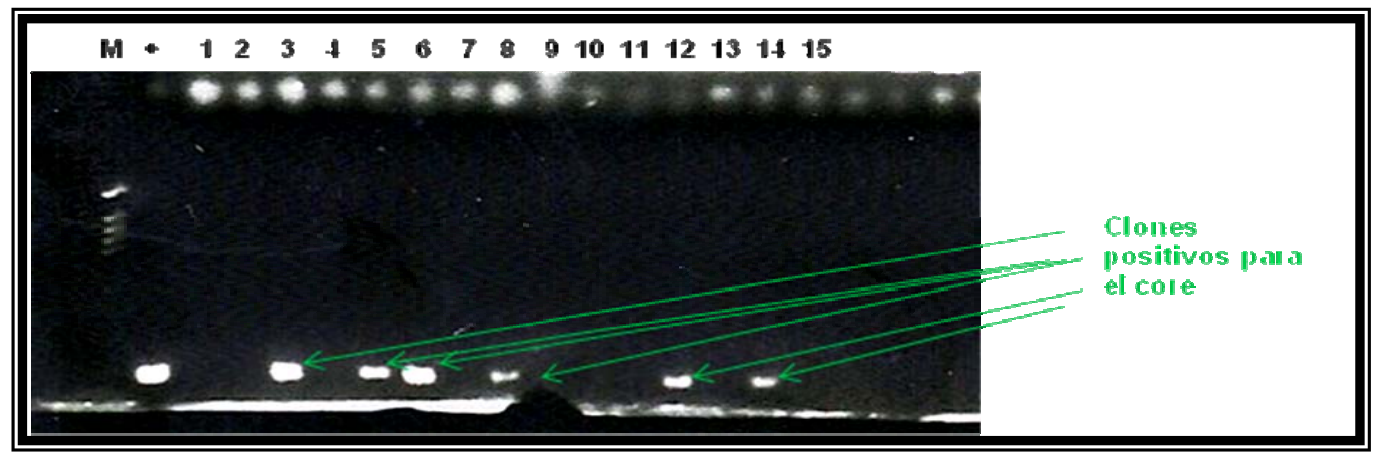

Figura 4: Electroforesis en gel de agarosa para identificar las colonias que han integrado el fragmento correspondiente al gen core.

Una vez secuenciadas, se seleccionaron los clones que no presentaban mutaciones, o bien, si había mutaciones, éstas eran sinónimas. Por ejemplo, en el caso de NS5A, el clon 14 no presentaba mutaciones; en el clon 11 había una mutación sinónima en la posición 1269 (TCC $\rightarrow$ TCT, serina); y en el clon 8 había una mutación sinónima en posición 1902 (GCT $\rightarrow$ GCC, adenina). Se seleccionaron los tres clones aunque el 14 era el mejor. En el caso del core, se seleccionaron los clones 6 y 14, en los que no se produjeron mutaciones.

\section{Resultados de la transfección y Western blot}

Como ya se ha mencionado anteriormente, la electroporación del gen core no funcionó bien y no se pudo evidenciar la expresión de la proteína mediante Western blot ni mediante tinción inmunológica. Al revelar el Western sí se observaba actina y el tag HA, pero no proteína core. En la tinción inmunológica de las células con anticuerpo anti-core no se observó proteína teñida al microscopio óptico (debería aparecer en color marrón).

Sin embargo, los resultados fueron distintos en el caso de la transfección con el reactivo FuGENE ${ }^{\mathrm{TM}}$. Antes de proceder a la realización del Western blot, se pudo comprobar mediante microscopía de fluorescencia que la transfección había tenido éxito, ya que en el control positivo (células 293 T transfectadas con plásmido GFP) aparecía una gran proporción 
de células que expresaban la proteína verde fluorescente, observándose fluorescencia en el núcleo (figura 5).

En el Western blot se apreció expresión de ambas proteínas, core y NS5A, aunque el core se expresaba de forma muy leve (figura 6).

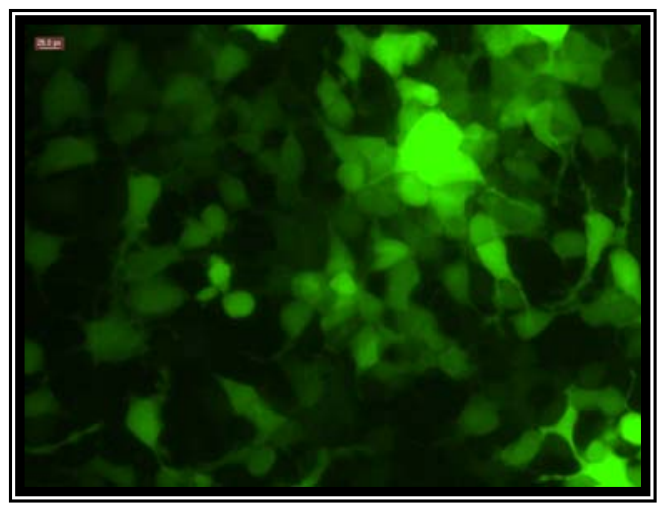

Figura 5: Resultado de la transfección de células 293T con el plásmido GFP.

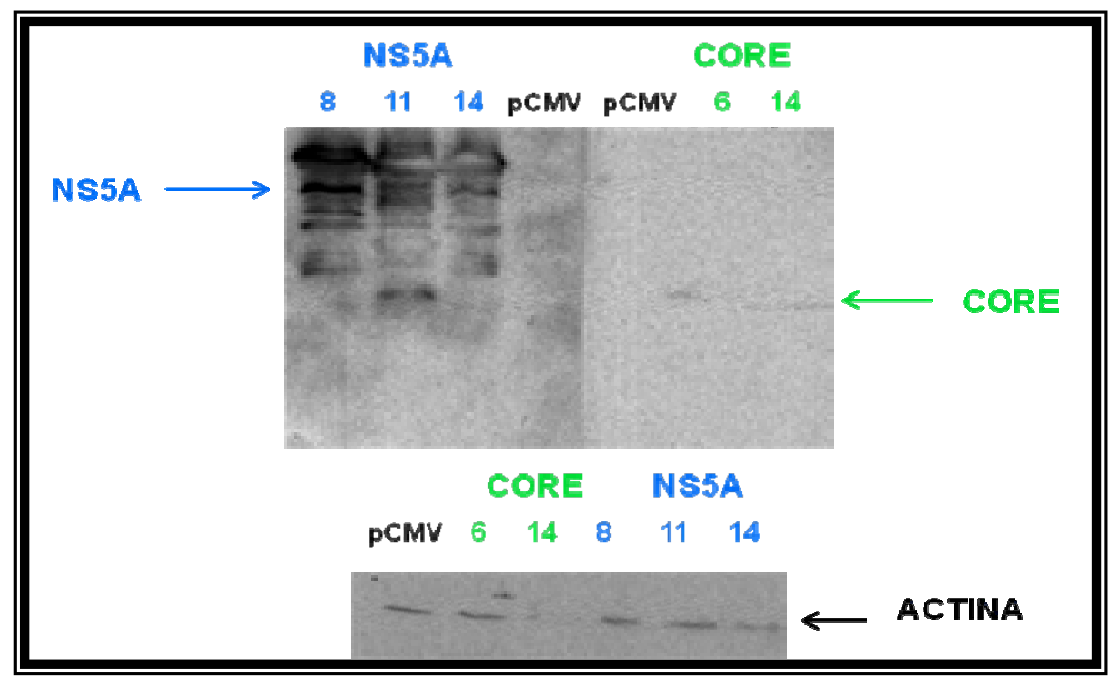

Figura 6: Western blot donde se aprecia la expresión de las proteínas core y NS5A en células 293T. Se había transfectado $1 \mu \mathrm{g}$ de ADN. Ratio FuGENE:ADN 3:1. Lisado de las células a las 48 horas de la transfección.

Para las células Huh 7.5 reporter, también se obtuvo una buena expresión de ambas proteínas, aunque la proteína core se seguía expresando de forma más leve (figura 7).

En cuanto al experimento de optimización de la transfección, se comprobó que había un mayor porcentaje de células positivas cuando se transfectaba en un ratio 6:1, teniendo en cuenta que las células positivas, señaladas con flechas blancas en la figura 8, eran las que 
aparecían fluorescentes tanto en el núcleo como en el citoplasma. Por tanto en los siguientes experimentos se utilizó este ratio.

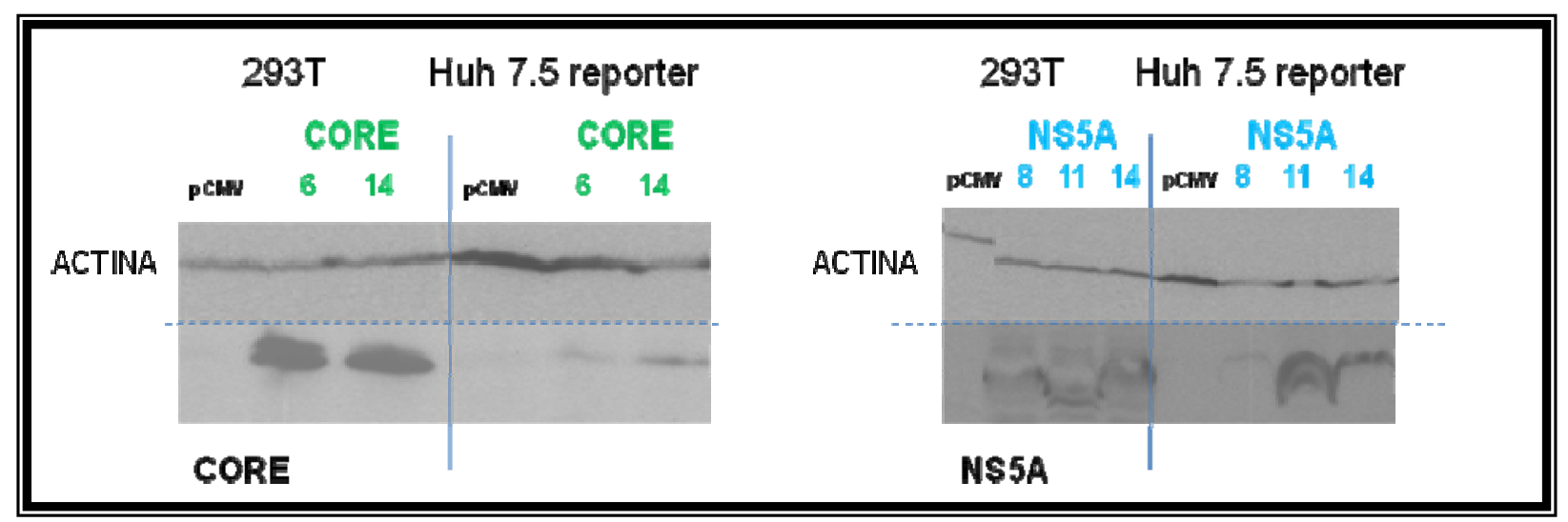

Figura 7: Western blot donde se aprecia la expresión de las proteínas core y NS5A en células $293 \mathrm{~T}$ y células Huh 7.5 reporter. Se había transfectado $2 \mu \mathrm{g}$ de ADN. Ratio FuGENE:ADN 3:1. Lisis a las 72 horas de la transfección.
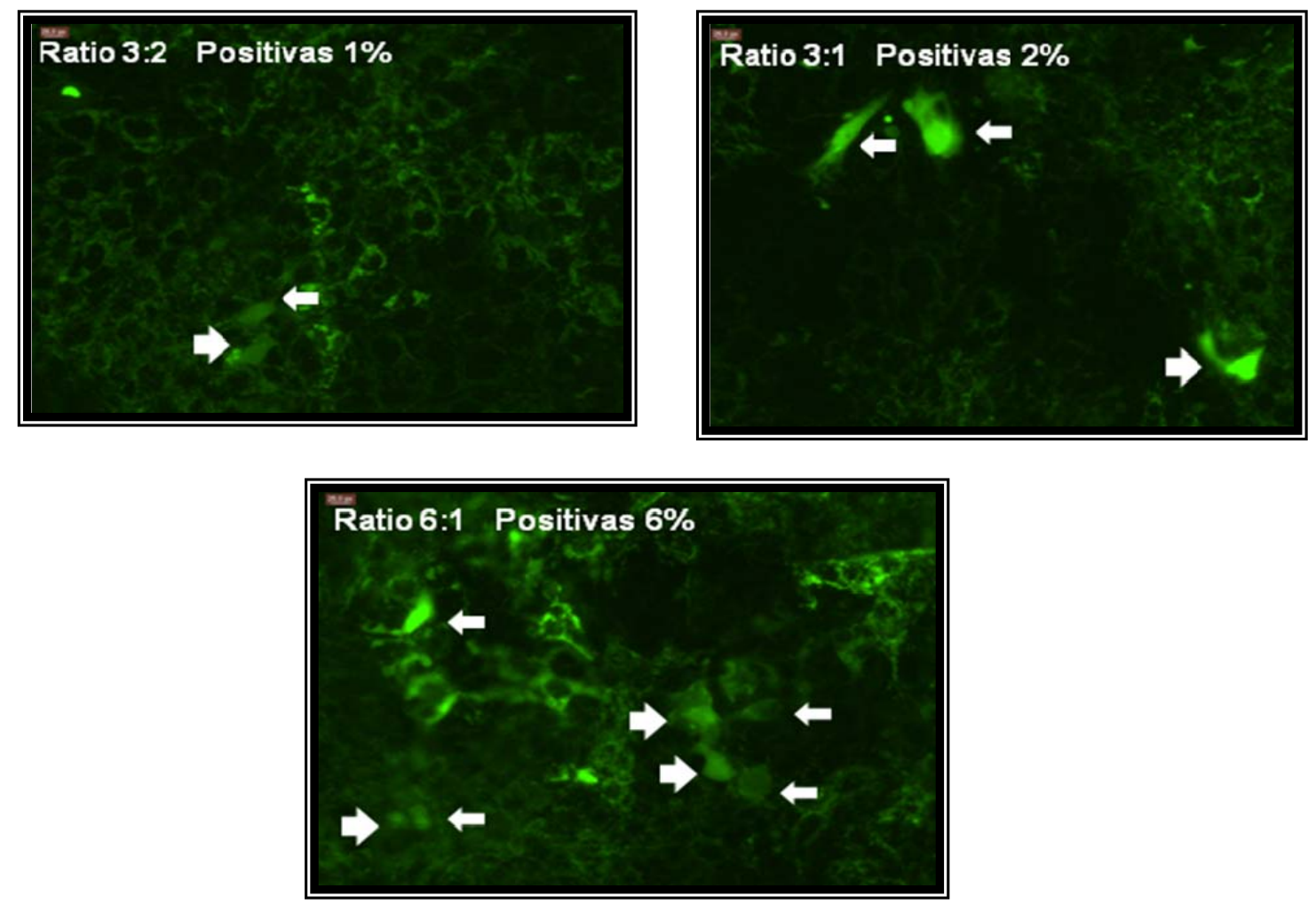

Figura 8: Imágenes con microscopio de fluorescencia que muestran células Huh 7.5 reporter transfectadas con plásmido GFP a diferentes ratios FuGENE:pGFP. Lisado a las 72 horas de la transfección. 
Finalmente se repitió todo el proceso a partir de dos cepas distintas de la Jc1 del virus de la hepatitis C, en concreto las cepas H77 (genotipo 1a), y Con1 (genotipo 1b). La secuencia de los cebadores diseñados para la clonación de estos genes ya se especificó en material y método. La amplificación, digestión, ligación y transformación de bacterias competentes se llevaron a cabo siguiendo los mismos protocolos. Las colonias que transformaron fueron las siguientes (figura 9):

- NS5A/H77: clones 12, 13, 14, 15, 16 y 17.

- NS5A/Con1: clones 6, 9 y 11.

- Core/H77: clones 8, 10, 11, 12, 14 y 15 .

- Core/Con1: clones 9 y 10.

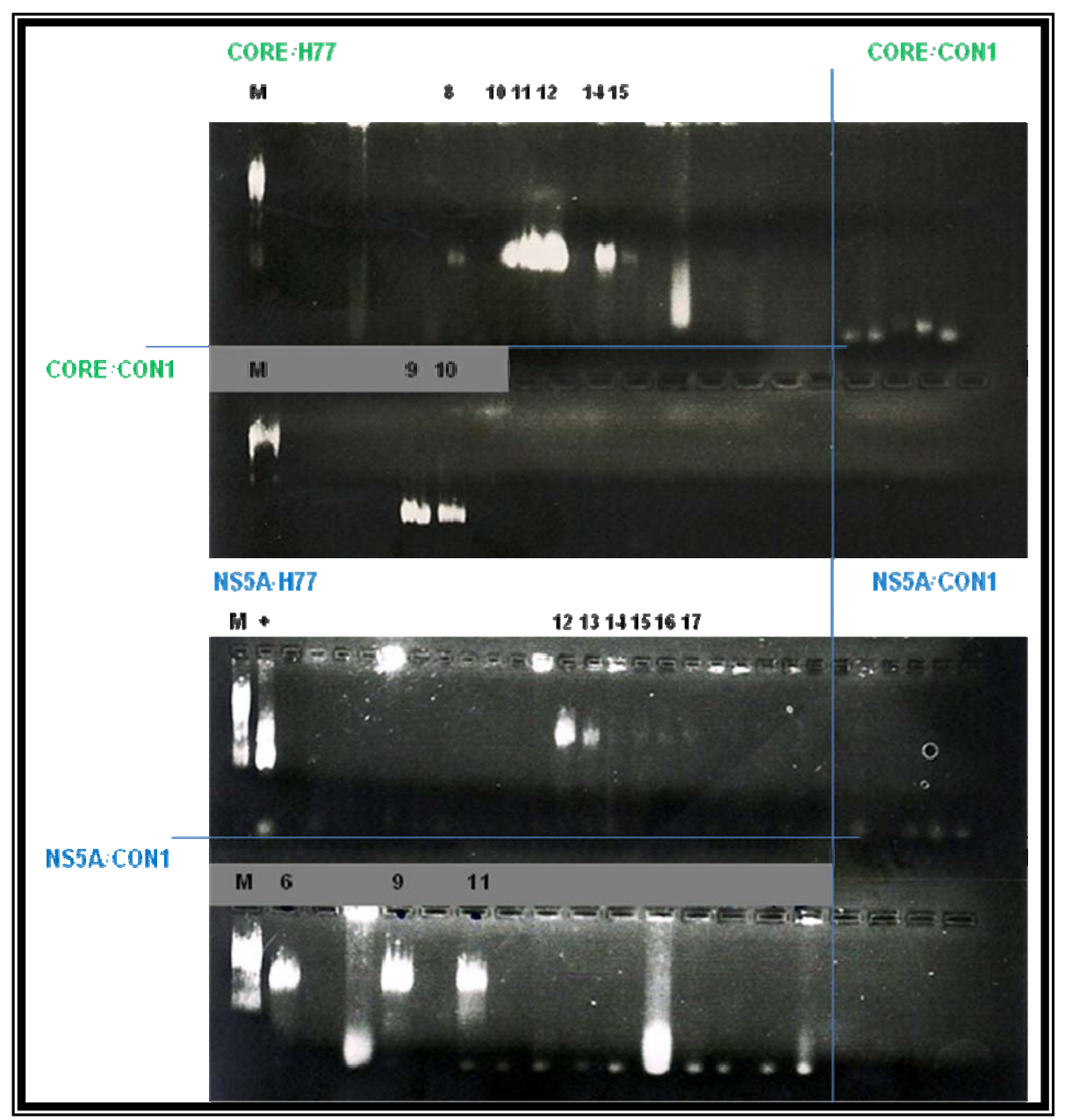

Figura 9: Electroforesis en gel de agarosa que muestra las colonias que integraron los fragmentos correspondientes a los genes core y NS5A de las cepas H77 y Con1. 
La mayoría de ellas presentaban una coincidencia del $99-100 \%$ con respecto a la secuencia consenso, y si había mutaciones eran sinónimas. Se seleccionaron los mejores clones:

- NS5A/H77: clon 15.

- NS5A/Con1: clon 6.

- Core/H77: clon 12.

- Core/Con1: clon 9.

La transfección se realizó con $1 \mu \mathrm{g}$ de $\mathrm{ADN}$ de cada una de las muestras, a un ratio FuGENE ${ }^{\mathrm{TM}}:$ ADN de 6:1, ya que esta proporción había resultado ser la más eficiente. Además de estas últimas muestras también se transfectaron pCMV-HA, pGFP, los clones 6 y 14 del core/Jc1 y los clones 11 y 14 de NS5A/Jc1. Se dejó incubar 72 horas a $37^{\circ} \mathrm{C}$ antes de proceder a la lisis celular y al comienzo del Western blot.

Para el Western blot se utilizaron los mismos anticuerpos en la misma proporción.

Los resultados del Western blot de las cepas H77 y Con1 se aprecian en la figura 10. También se obtuvieron buenos niveles de expresión, y es importante destacar cómo se aprecia la diferencia de tamaño entre las bandas correspondientes a la proteína NS5A de la cepa Jc1 con respecto a la de las cepas H77 y Con1, debido a una inserción de unos 20 aminoácidos presente en la de la cepa Jc1, que por tanto tiene un tamaño mayor y aparece en una posición superior en el gel de poliacrilamida.

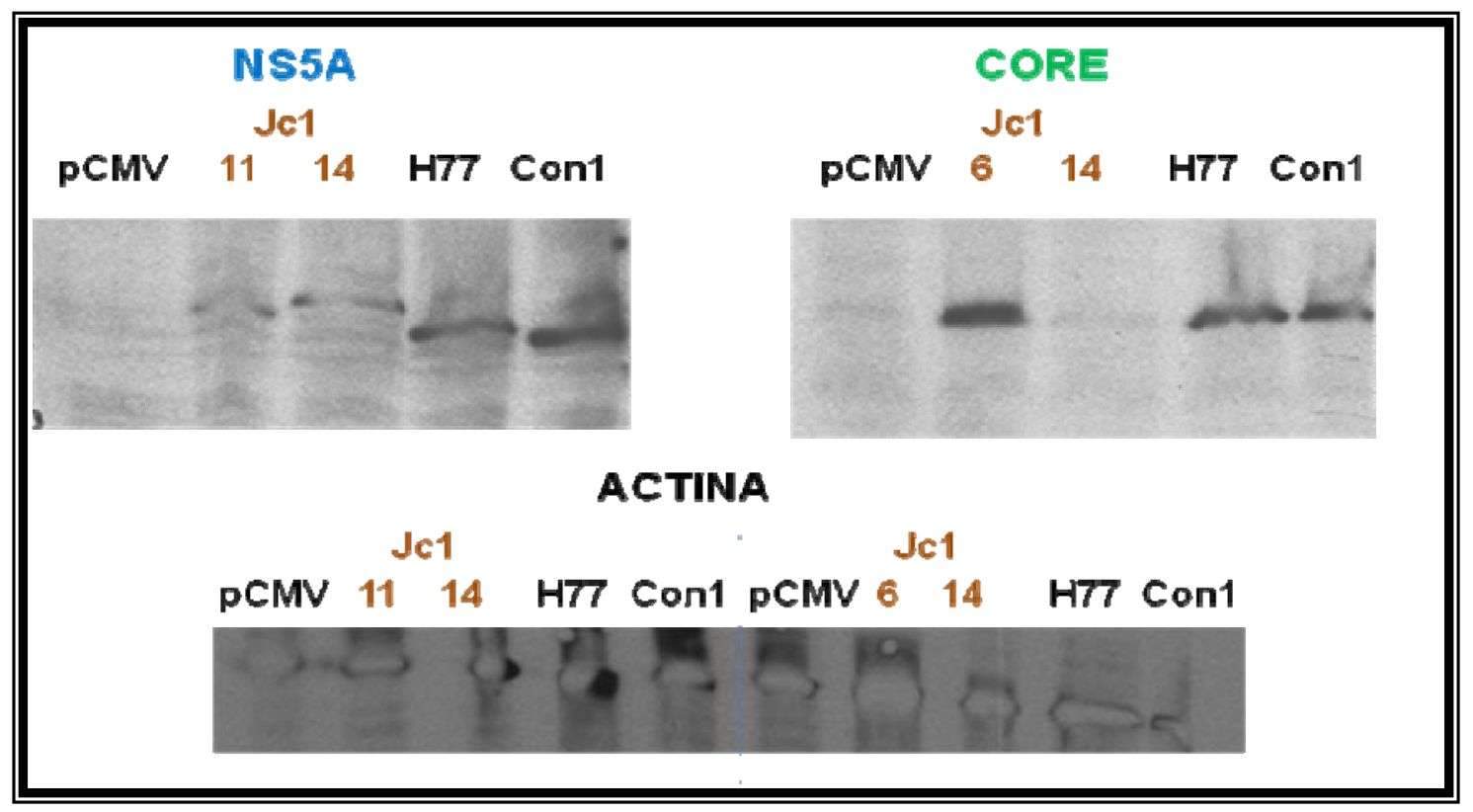

Figura 10: Western blot que muestra la expresión de proteínas en las tres cepas utilizadas en este trabajo. 


\section{DISCUSIÓN Y CONCLUSIONES}

El virus de la hepatitis $\mathrm{C}$ es capaz de causar infecciones persistentes en individuos susceptibles, y está implicado en el desarrollo de cirrosis hepática y carcinoma hepatocelular en muchos de estos pacientes. No se conocen con exactitud los mecanismos que intervienen en estas patologías, y es importante avanzar en el conocimiento de la biología de este virus para el desarrollo de nuevas terapias. Sin embargo, este avance se ha visto retrasado por la falta de modelos apropiados de replicación e infección, y no fue hasta el año 2006 que se consiguió generar partículas virales infecciosas en cultivo celular, gracias al aislamiento de la cepa JFH-1 a partir de un paciente con hepatitis fulminante (Kato et al, 2006).

Actualmente el trabajo con cultivos celulares se hace casi indispensable para el estudio de muchos virus, y es el punto de partida para muchos experimentos. En el presente trabajo se ha conseguido clonar los genes de dos proteínas esenciales en la replicación del virus de la hepatitis $\mathrm{C}$ y expresar estas proteínas mediante un sistema utilizado habitualmente en el laboratorio. Además, se ha conseguido no sólo con una cepa de genotipo 2a (Jc1), sino también con los genotipos 1a y $1 \mathrm{~b}$ (H77 y Con 1 respectivamente), lo que es especialmente interesante en cuanto a futuros experimentos, ya que se ha visto que la respuesta al tratamiento varía según el genotipo del virus presente en el individuo infectado.

Se intentaron dos métodos de transfección: uno de ellos fue la electroporación y el otro fue la transfección mediante el reactivo FuGENETM. Con el primero no se obtuvo expresión de proteína core, sin embargo el Western blot puso de manifiesto que sí había habido transfección, ya que se detectó el epítopo HA. Se piensa que no se detectó proteína core debido a la necrosis de una gran cantidad de células a causa del choque eléctrico, de modo que la cantidad de proteína core presente era indetectable.

A pesar de que las células de hepatoma son muy sensibles y no son pocas las dificultades a la hora de transfectar, se ha podido desarrollar un buen sistema de expresión en esta línea celular además de en células 293T, y también se ha optimizado un sistema de transfección que permite expresar una alta cantidad de las proteínas core y NS5A del virus.

En próximos experimentos se tratará de clonar otras proteínas del virus y se intentará aumentar la eficiencia de transfección, ya que se considera que el 6\% que se obtuvo con el ratio 6:1 es aún bajo y puede mejorarse.

A partir de aquí se pueden realizar numerosas investigaciones sobre el virus de la hepatitis $\mathrm{C}$, como por ejemplo experimentos de mutagénesis dirigida para incrementar el conocimiento sobre las funciones que realizan estas proteínas; se pueden expresar ambas proteínas simultáneamente en una célula para estudiar las interacciones entre ellas; y también 
se puede profundizar en qué alteraciones se producen en las histonas cuando se expresan esas proteínas en la célula.

\section{AGRADECIMIENTOS}

Quiero agradecer a todo el laboratorio 121 del Centro de Biología Molecular Severo Ochoa, con el Dr. Esteban Domingo al frente, todo el apoyo que me prestaron para la realización de este trabajo, en especial la labor docente de la Dra Julie Sheldon que hizo posible la correcta realización de los experimentos.

\section{BIBLIOGRAFÍA}

Bartenschlager, R., Cosset, FL. y Lohmann, V. 2010. Hepatitis C virus replication cycle. J Hepatol 53: 583-585, doi 10.1016/j.jhep.2010.04.015.

Esteban, JI., Saudela, S. y Quer, J. 2008. The changing epidemiology of hepatitis C virus infection in Europe. J Hepatol 48: 148-162, doi 10.1016/j.jhep2007.07.033.

Gao, M., Nettles, RE., Belema, M., Snyder, LB., Nguyen, VN., Fridell, RA., Serrano-Wu, MH., Langley, DR., Sun, JH., O’Boyle, II DR., Lemm, JA., Wang, C., Knipe, JO., Chien, C., Colonno, RJ., Grasela, DM., Meanwell, NA. y Hamann, LG. 2010. Chemical genetics strategy identifies an HCV NS5A inhibitor with a potent clinical effect. Nature 465: 96100, doi: 10.1038/nature08960.

Herceg, Z. y Paliwal, A. 2011. Epigenetic mechanisms in hepatocellular carcinoma: How enviromental factors influence the epigenome. Mutat Res 727: 55-61, doi: 10.1016/j.mrrev.2011.04.001.

Huong, TL., Yun-Sook, L. y Soon, BH. 2010. Establishment of interferon alpha-resistant hepatitis C virus using cell culture system. FEBS Letters 585: 409-414, doi: 10.1016/j.febslet.2010.12.028.

Jones, CT., Catanese, MT., Law, LM., Khetani, SR., Syder, AJ., Ploss, A., Oh, TS., Schoggins, JW., MacDonald, MR., Bhatia, SN. y Rice, CM. 2010. Real-time imaging of hepatitis C virus infection using a fluorescent cell-based system. Nat Biotechnol 28, $167-$ 171, doi:10.1038/nbt.1604.

Kato, T., Date, T., Murayama, A., Morikawa, K., Akazawa, D. y Wakita, T. 2006. Cell culture and infection system for hepatitis C virus. Nature Protoc 1, 2334-2339, doi: 10.1038/nprot.2006.395. 
Kopp, M., Murray, CL., Jones, CT. y Rice, CM. 2009. Genetic analysis of the carboxyterminal region of the hepatitis C virus core protein. J virol 84, 1666/1173, doi: 10.1128/JVI.02043-09.

Lauring, AS. y Andino, R. 2010. Quasispecies theory and the behavior of RNA viruses. PLoS Pathog 6: 1-8 doi:10.1371/journal.ppat.1001005.

Moradpour, D., Penin, F. y Rice, CM. 2007. Replication of hepatitis C virus. Nature Rev Microbiol 5: 453-463, doi 10.1038/nrmicro1645.

Tong, X. y Malcolm, BA. 2005. Trans-complementation of HCV replication by non-structural protein 5A. Virus res 115: 122-130, doi: 10.1016/j.virusres.2005.07.012. 